\title{
Adaptive reuse for Dutch East Indies colonial building: Connecting identity, memory and social media in De Tjolomadoe
}

\author{
A A S Fajarwati \\ Interior Design Department, School of Design, Bina Nusantara University, Jakarta, Indonesia
}

ade@binus.ac.id

\begin{abstract}
The heritage buildings from Dutch colonial period in Indonesia had sustained transformation in pursuit to survive. Formerly space designed for the activity needs at that time, changed the architectural and interior functions into commercial space. Despite the fact that the shape of the building does not change, the function transformation is required since it must be adapted to today needs as the changes of time. In De Tjolomadoe, the role of colonial building is revitalized, which consumers can enjoy even though it means altering the meaning of origin. This new settings become popular visual backgrounds to occupied the needs of self-actualization in social media. Consumers that were born from the present day, are trying to feel the sensation of moving to the past through colonialism atmosphere. There were changes in the identity space, exploration of memory in the development of social media makes this building continues to survive and sustainable. This research focused on how transformation is taking place on conservation building's identity when it is converted into a commercial space and why this change is accepted by society.
\end{abstract}

Keywords: Colonial, Heritage, Interior, Social Media

\section{INTRODUCTION}

Dutch colonialism in Indonesia that took place between the 17th and 19th centuries, has left the colonial buildings that have supported the needs of the Dutch East Indies at that time. Various types of colonial buildings designed to fit for human activities 200-300 years ago as a daily life support such as human settlements, government offices, fortresses, shops to factories that produce plantation products in Indonesia at that time. The Javanese exploration of plantations combined with the liberalization of European economies, speed up the development in the 19th century, where plantation and rest areas became cities, and commercial cities grew into large cities in early 18th century. [1] The colonial building architectural form has a special mark that distinguishes from the local community building which refers more to tradition. The influence of European buildings combined with the tropical environment of Indonesia, creating a new identity of colonial building Indonesia that is similar to the building in Europe and also has the characteristic of tropical building that are suitable for Indonesian people, both from the shape of the facade to the interior. This colonial building has characteristic of high walls, wide windows, symmetrical layout arrangement, to the space filler ornaments with European culture influence. While the size that is shorter than the european building with rising roof just as where the traditional Nusantara building, and the canopy placement that protects the window or door from the rain as it is the characteristic of the tropical region is a typical building adaptation from Dutch colonial period at the end of 19th century. 
Space is designed based on the required activities. European body shape that tend to be higher and bigger than the Indonesian, affect the spatial layout design and furniture selection from the Indonesian colonial buildings. As the Dutch colonialism ended, it made all infrastructure changed hands. Some colonial buildings were taken over by the government, agency, private sector and private property. As artifact that has identity in the history of Indonesian civilization, the building is maintained and conserved by law. Owners may manage, but are not permitted to spoil or restore without permission, and as much as possible to keep maintain the original building condition. For conservation heritage buildings, there are options: preserved, restored, reconstruction, revitalization (adaptive) and demolition (destructions). Those choice depends on the building condition and the stakeholders who take decision. Sengupta. I (2017) said that historical structures were to be preserved, rather than restored; necessary 'beautification' of such structures was to be undertaken. Historical structures were thus rendered 'monuments', which were to be visited and seen from a distance, not regarded as part of living tradition or social and ritual practice [2]. But, mostly heritage buildings in Indonesia do revitalization to conserve. The hundreds years of age from the old buildings has a considerable risk of damage, and requires a strong financial backing from its managers. When the building is functioned and maintained in its original form, it sometimes becomes heavy to do as the current environmental conditions have changed. Humans have different needs over time. However, maintaining this form of conservation building is also an important need as a heritage of identity caretaker. Heritage buildings from the Dutch colonial era, is getting a functional shift as a form of representational change practice currently, therefore right now the building is understood, produced, displayed and used to meet the different needs if compared with the needs at the time when the building was established.

The representation meaning's change, is a popular culture category as a structure involving the hegemonic power in the reproduction process. As stated by Abidin, (2009) that the content, form and space of the city forms cultural politics, identity and collective memory, culture is a key political and social control, the power of the power at any time, causing the deconstruction of meaning, including the architectural building of the colonial period Netherlands [3]. Hall's Cultural Circuit has described five key concepts of cultural relations are interlocked without having to constantly be on the order of: representation, identity, reproduction, production, consumption and regulation [4]. Historic buildings utilization that exploited for commercial space as the identity of the building is related to the collective memory. People connect to historic buildings not only on how the building can be remembered physically but also how the buildings represent the collective memories of people [5]. The changing identities and space function, which is connected to visitor memory, keeps this building physically maintained and sustained. Environment still owns the building in the form of conservation, but able to be explored in the current concept life styles.

\section{METHOD}

This research will use qualitative method in the form of observation and literature study. The author conducted data collection through direct field observation, literature study from journals, books, or sources from the web, from writings that related to adaptive reused, identity, memory applied in sustainable practice. Moreover direct observation also conducted through site survey at De Tjolomadoe as colonial building, in order to obtain comprehensive data. 


\section{RESULT AND DISCUSSION}

Colonial authority in Java in 18-19 century, penetrated on farm sector that support the Netherlands economy. The practice of Cultur stelsel, that forced people to plant of plantations and crops, which is in harmony with the infrastructure development needs such as office and residential mill plantation workers. As time goes by, these buildings are no longer defined as when it was established. Such as the cessation of production of some factories that are hundreds of years old, which was founded from the Dutch period in several places, causing the buildings can no longer function as it should, so broken and not well maintained. The inadequate maintenance of colonial buildings which was then controlled by the state, resulted in the dysfunction of a productive room, with a large area. The present political powers and economic power are followed by utilization to function towards needs that is more commercial and popular, as the priority in the present. Mostly colonial buildings in Indonesia adapt the building with mixed use. This approach kept the original function of the building as it is and supported by additional functions for the sustainability of the heritage building. The strategy adaptive reuse project cannot be applied for all kind of heritage buildings since it depends the values of the heritage building [5]. Adaptive reuse project divided by Misırlısoy, D., \& Günçe, K., (2016) as three categories, first option is to use the building with the original function with some necessary adaptation to fit the building for today's requirements, mixed use which the original function of the building is kept as it is supported by additional functions for the sustainability of the heritage building, and adaptation of the building with totally new use [6].

\subsection{About De Tjolomadoe}

For example P.G. Colomadu, a sugar factory in Surakarta, which is now become De Tjolomadoe. This building was originally established December 8, 1861 by KGPAA Mangkunegoro IV at his glory day as an agro-industries pioneer in the country. Created by architect from Germany, R. Kamp, it facilitated many Dutch labor activity. With Indische Empire style from Daendels leadership at Dutch Indies, it shows a transition architecture, which is a combination of Dutch style and tradition buildings of Indonesia. At that time, the Dutch East Indies can not follow the development of architecture in Europe because of the location which is very much even though many of the workers there. Therefore buildings that combined european and tradition styles called Indische Empire styles building came up. It has physical attributes such as symmetrical interior, thick walls and high ceilings. There are Greek columns, that in its development replaced by iron pipe, and zinc material that protects the windows and the front porch of rainfall splash, as tropical area characteristic [7].

In 1996 the sugar factory of Colomadu was handed over to PTPN IX (a state-owned company that handled the plantation). But government policy on May 1, 1998, decided to stop P.G Colomadu operational because of financial losses. Two years since the factory handed over to PTPN IX it begin to stop its production and loss in maintenance. The government change affects the policy change in every historical building. Culture has the same breath with its time. Science and art as cultural expression will be determined by the main patron, that is government. At the era of President Joko Widodo, there is a decision change to revitalize PG Colomadu. As a respect to this building historical value, in 2017 PG Colomadu revitalized by the company in the BUMN (State Owned Enterprises). This former factory buildings was cleaned, polished, and 
re-displayed into the original form with a more contemporary shape. The name of this building was changed to De Tjolomadoe.

\subsection{Adaptive reuse the colonial building}

This place is then used as the central place of cultural events from theaters to tourist attractions, from museums, cafes, to the concert hall. The physical condition of this building that was founded 157 years ago does not change too much. For about 19 years the building was stalled, and the engine in the factory is stop working.

Some steps need to be taken as a sustainable effort to be able to continue to use the old building even with functions that may differ from its origin. As a conservation building, it is not possible to demolished and replaced it with other building that is more functional. The interior of previous function lacking space, then converted while maintaining the building original shape. Floor is revitalized with color composition which makes the room look more contemporary. Giant machines that previously are scrap metal then exposed and the color is changed with attractive setting concept. The factory, which previously used standard light illumination, was modified with attractive light arrangement and made visitors comfortable. Previous room that tended creepy, unkempt, dingy, converted into an interesting spot as a museum as well as a music performances building to a cafe that support the visitors consumption needs.

Visitors use the former factory building to take pictures with various room settings that is not easily obtained in other public spaces. As concert hall with an international-level performance building, De Tjolomadoe presents international and national artists that bring thousands of audience. The use of sound technology and lighting performance is required to support a show. The strength of the building is related to the vibration scale of the sound at the show performance, become a consideration when changing the function of the building. From consideration to put the silencer, the calculation of the sound reflection, selecting the furniture, become interior designers consideration in creating new space functions that can run well.

The purpose of revitalizing dead buildings to make it lively and productive is a rescue effort. Conservation to heritage building could be happen without loosing its characteristic includes styles and ornaments. As Günçe and Misırlısoy describe that heritage values, physical characteristics and potentials of the heritage building should be well analyzed holistically, adaptive reuse of a heritage building is a challenging process. [8 ] Adaptive reuse is an alternative to demolition and replacement of buildings since it requires less energy and waste. To find the most appropriate use of conservation for historical heritage buildings, in-depth analysis is needed before new decision making is made. Physical characteristics of architectural heritage is crucial things includes location, physical dimension, structure system and location of structural elements, construction techniques and materials, number of story, style/period, physical condition, spatial organization, formal/ façade characteristics and natural lighting [6].

As a museum, De Tjolomadoe can serve to build community togetherness, as they provide a place for fellow citizens to interact and make collective moments each other. A new meaning is coming up from an old factory room, into a showroom. The meaning appropriation of the public space is an activity that involves discourse of remembrance, neglection and oblivion. Public space contribute to the contours of our memory. The past experiences memory understanding are attached (of course not all of them) and active in our minds, so it formed us. Our relationship with memory also depends on our ability to accumulate previous experiences. The collective memory comes from collective forgetting. Personal memory and collective memory are depend on the place, in a concrete physical space, because it has longer life than 
humans. The past is not eliminated, but is raised again as the form of old buildings revitalization to form new memories [7].

\subsection{Eksploration identity and memory}

Then comes the question, which period identity belongs that is exploited? Is it a colonial building of a sugar factory that was formed by the colonial era 157 years ago, or a new museum and entertainment space that meets the needs of today's society and the building as its setting? Whoever identifies with it and thus claims it as theirs. Actually what emerges is a building identity that is a combination of both, the identity created in the colonial period, as well as the identity that appears in the present moment.

The visitors of De Tjolomadoe are dominated by children who are accompanied by their parents and teenagers that come with their groups comes with photo equipment and photographed each other by taking every corner of the room as a setting. Captured photos of the space, are digitalized in visual form, shaping an exciting new experience for visitors. Some people may attend to know the history about how a sugar factory was once established but then stopped and also studied all the historical backgrounds of the colonial buildings. Museum has a function as a place of education but it can also serves as a place of entertainment [8] and it is the most sought after by visitors. When visitors are entering De Tjolomadoe, the ambience is no longer as an old factory, but an entertainment space. The identity as a factory building seemed to be disguised by a new interior arrangement that formed a new identity as a museum. The building has not changed, nor the placement of factory machinery that characterizes and used as an interior setting that entertain visitors. Rabun and Kelso have opinion, a building, which the adaptive reuse will be applied with change of use, must be evaluated both the exterior and the interior and also the assessment of an existing building must be done in a comprehensive manner [9].

The identity of the sugar factory in Colomadu, that holds thousands of underlying stories, is become added attraction. Although visitors can see that the origin of the building is a sugar factory, visitors seemed to witness a friendly and comfortable entertainment space that is lovable to share in social media. It show a lot of different from the impression of an old factory that is heavy, gloomy, stuffy space to work. Identity is still the memory's goal although some efforts of conservation may be notable to discover the importance of the building and the past facts. History prioritizes truth while memory is content to reorganize the past to create an identity of the urban area [10]. We may not know exactly how the relationship of revitalization of colonial buildings with the transformation of identity, but the existence of comparative elements from ambience to visitors who are in it, helps us tu understand that the times have moved, and the era of the authority has changed. The old identity of the sugar factory, becomes a problem as well as a solution for interior designers. The role of the interior designer to take advantage of the old identity of this sugar factory, becomes a problem as well as solutions. As for conservation building it is a must to keep its original shape of the building as much as possible. On the other hand, it turns out that the former building can be utilized into a decoration space. The colonial building can be further explored as it has representative space setting and commercial value. Large, old wooden doors that are rarely found today, peeled off brick walls, dead machinery, into new exploration that interest to visitors in the present.

Colonial setting is an attraction for consumers to visit or conduct transactions in spaces over the function. Some investors even bet on investing some capital to have management power in colonial architecture building. One of the reasons for investing in colonial buildings to converted it into public space are the settings that have been purchased, as well as the story and meaning 
of the colonial period that can be explored again to attract the public further. The players in preparation and application of the conservation project are the producers. Producers that hired by investors can be changed from project to project and includes architect, designer, engineer, restoration expert and specialist [6]. At the beginning of the 19th century when the building was established, the context of the status and the identity was characterized by the appearance discourse. It was obvious at that time anyone who can access the factory environment or just become audience outside the building. However when the function of the building is converted into a public space, the human identity within it becomes biased. Anyone who is interested to visit, have the same opportunity to enjoy the memories, both individual and collective memory. Interesting categories of public spaces that keep stories, from true stories or mystical, become a magnet for visitors to enjoy the moment of meaning in a colonial buildings.

The need to display the space and story setting behind a room, packed beautifully in the social exposure of human media today. Inevitably, the virtual world that is represented in space in the form of an uploading device become a new world for people today. The visual of "Instagrammable" room allows visitors to express themselves in social media as a pop culture need, as well as making them and previous generations able to experience the sensation of exploring different times and spaces, both nostalgic and the world that they had never explored. Visitors have forgotten that the previous colonial building have been untreated, damaged and unattractive. By changing with adaptive reuse, make this building survived and sustainable in an environment that developed over more than one a half century.

\section{CONCLUSION}

The adaptive reuse function of an interior design that changes from the beginning of the building was planned, undergoes changes of identity. However, the identity of the building prior to the transfer of function which is a residual culture that sought by today's society, related to collective memory and lifestyle include connect with social media. The colonial form of preserved remains a historic relic that links the identity of humanity in the past, although the function of the Dutch colonial heritage buildings in Indonesia has been altered and adapted to the present human needs.

Interior designers involved in this displacement function can take advantage of the condition of the building as a commercial setting, despite the shift in the meaning of the building. Appeared later a new identity of this building, which can be accepted by humans today, but still keep some of the identity in the past as a part sustainable movement. The functional shift of a room that changes from the beginning of the building is planned, undergoes change of identity as well. However, the identity of the previous building prior to the functional shift is a residual culture that is sought by people nowaday, related to collective memory and lifestyle that connected with social media. The form of colonial building that preserved as a historic relic that links to the identity of people in the past, although the function of the Dutch colonial heritage buildings in Indonesia has been altered and adapted to the present human needs. Interior designers that involved in this functional shift can take advantage from the building condition as commercial setting, despite there are shift from the meaning of the building.

A new identity of this building appeared later, that can be accepted by people nowadays, but still keep some of the identity in the past. Colonial heritage buildings which once nearly extinct, could eventually be used and continuing today with a joint identity between the past and the current that exists in the memory of visitors, in the recording of human memory, as well as in exploration in social media. This suistainable practice of colonial building creates a new space that is received and enjoyed by visitors with a link memory of the past or the present. 


\section{ACKNOWLEDGMENTS}

The author gratefully acknowledges that the present research is by personal and dedicated this research for Interior Design Department, Bina Nusantara University Jakarta, Indonesia.

\section{REFERENCES}

[1] R. Sunaryo and I. and S. B. Soewarno N, "Pengaruh Kolonialisme Pada Morfologi Ruang Kota Jawa Periode 1600-1942," in Seminar Nasional Riset Arsitektur dan Perencanaan (SERAP) 3, 2014.

[2] I. Sengupta, "Preservation between empire, nation and nationalisms: the problem of history and heritage in India," Nations Natl., vol. 24, no. 1, pp. 110-130, Jan. 2018.

[3] A. Kusno, L. Kurnia, and M. Budiman, Ruang publik, identitas dan memori kolektif: Jakarta pasca-Suharto. Yogyakarta: Ombak, 2009.

[4] S. Hall, J. Evans, and S. Nixon, Representation. London: Sage Publications, 2013.

[5] Y. Nurliani Lukito and A. Nurul Rizky, "Collecting memories of the city through the conservation of heritage building," IOP Conf. Ser. Earth Environ. Sci., vol. 126, p. 12081, Mar. 2018.

[6] D. Misırlısoy and K. Günçe, "Adaptive reuse strategies for heritage buildings: A holistic approach,” Sustain. Cities Soc., vol. 26, pp. 91-98, Oct. 2016.

[7] J. A. Koeswandi, "Ekspresi Gaya Arsitektur Kolonial pada Desain InteriorGedung Lindeteves Surabaya," e-Jurnal Eco-Teknologi UWIKA, vol. 1, no. 2, pp. 43-48, 2013.

[8] K. Günçe and D. Misirlisoy, "Adaptive reuse of military establishments as museums: conservation vs. museography," WIT Trans. Built Environ., vol. 143, pp. 125-136, Sep. 2014.

[9] J. S. Rabun and R. M. Kelso, Building evaluation for adaptive reuse and preservation. Hoboken, N.J: John Wiley, 2009.

[10] J. V. Wertsch and H. L. Roediger, "Collective memory: Conceptual foundations and theoretical approaches," Memory, vol. 16, no. 3, pp. 318-326, Apr. 2008. 